\title{
Price Effects of VAT Introduction in Croatia
}

Dalić, Martina

Source / Izvornik: Occasional Paper Series, 1997, 1, 1 - 19

Journal article, Published version

Rad u časopisu, Objavljena verzija rada (izdavačev PDF)

https://doi.org/10.3326/ops.4

Permanent link / Trajna poveznica: https://urn.nsk.hr/urn:nbn:hr:242:363645

Rights / Prava: Attribution-NonCommercial-NoDerivatives 4.0 International/ImenovanjeNekomercijalno-Bez prerada 4.0 međunarodna

Download date / Datum preuzimanja: 2023-04-26

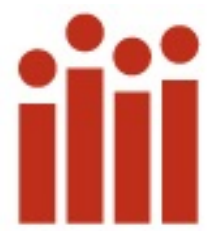

Repository / Repozitorij:

Institute of Public Finance Repository

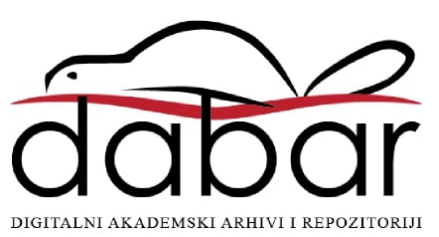




\title{
PRICE EFFECTS OF VAT INTRODUCTION IN CROATIA
}

\author{
Martina Dalić \\ Occasional Paper No. 4
}

December 1997

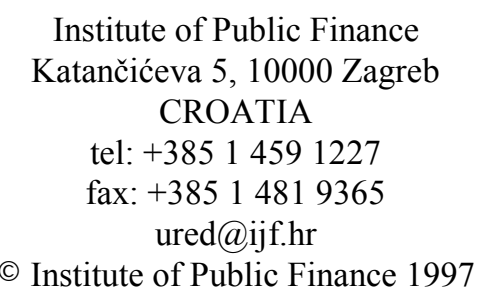




\title{
PRICE EFFECTS OF VAT INTRODUCTION IN CROATIA
}

\author{
Martina Dalić
}

This Occasional Paper is based on the research project "Analysis of the fiscal system of the Republic of Croatia at the introduction of value added tax" undertaken by the Institute of Public Finance and financed by the Ministry of Finance of the Republic of Croatia. Starting from the research project and the paper published in Croatian in the Institute's journal "Financijska praksa", Volume 20, Number 2 (August 1996) the revision of results was undertaken and presented in this Occasional Paper. The revision of original results was necessary because of changes in Croatian sales tax which were put in force after the Institute's project has already been completed.

The author of this paper is Martina Dalić (Ministry of Finance of the Republic of Croatia). The author thanks Danijel Nestić (Economics Institute, Zagreb), Saša Mađarević (Ministry of Finance of the Republic of Croatia), and Zdravka Barac and Zlatko Fabijančić (Tax Administration of the Republic of Croatia) for helpfully providing data and giving useful comments.

The views expressed here are those of the author, and not necessarily those of the Ministry of Finance. 
ABSTRACT

The value added tax (VAT) will be introduced in Croatia on January 1, 1998. As a single rate tax of $22 \%$ with the very narrow scope of exemptions it will replace the current retail sales tax on goods and services. The nature of the price effects caused by the introduction of VAT is an issue with which all countries that currently apply VAT were faced both during preparations for its introduction and during the period immediately following. The requirement to study the possible price effects of VAT introduction is particularly important in a country such as Croatia, where memories of inflation and hyperinflation are still fresh, and inflationary expectations are still present. Depending on the degree of cascading prior to the wholesale stage (which we were not able to capture) it is possible to conclude that there is certain amount of room for the aggregate price increase. Taking into account that in the first months of VAT introduction there will be some difficulties, and assuming that prices will not display perfect downward rigidity, the forecast shows that the aggregate rise of prices (measured by the retail price index) could be a maximum of $3.27 \%$ (optimistic scenario) or a maximum of $5.2 \%$ (pessimistic scenario) - both on the assumption of zero cascading before the wholesale stage. 


\section{PRICE EFFECTS OF VAT INTRODUCTION IN CROATIA}

The nature of the price effects caused by the introduction of a value added tax (VAT) is an issue with which all countries that currently apply VAT were faced both during preparations for its introduction and during the period immediately following. Although both theoretical considerations, and the experience of countries that already apply VAT, lead one to conclude that VAT brings about a one-time change in prices and nothing else, the uncertainty introduced into the economy by such a significant fiscal reform is too great to be ignored. The requirement to study the possible price effects of VAT introduction is particularly important in a country such as Croatia, where memories of inflation and hyperinflation are still fresh, and inflationary expectations are still present.

The value added tax will be introduced in Croatia on January 1, 1998. As single rate (22\%) VAT with the

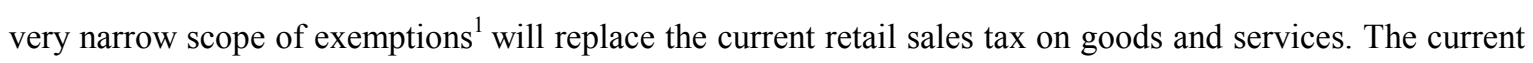
four-rate retail sales tax on goods is generally applicable in the retail phase with the suspension rule operating for all phases in the production-distribution chain prior to retail. However, a certain degree of cascading is present because several goods ( the most important being oil) are taxable in all phases of the value-added chain. Furthermore, the single rate $10 \%$ tax on services is applicable on all services. The tax on services also introduces cascading into the system because wholesales as well as retail sales are defined as services.

The characteristics of the current system of indirect taxation and the cascading it produces still further add to the importance of the question of the price effects of VAT introduction. We shall consider below the chosen method for assessment of the price effects of VAT in Croatia and the results of this method.

\section{Concerning the estimation method and data}

The determinants of price behaviour in the period after VAT introduction are many. It is clear that the introduction of VAT will affect relative prices and patterns of demand which means that a new income and price elasticity will be established. The price effects of VAT introduction also depend on the interaction and interrelations among many other factors. Monetary and exchange rate policy, the behaviour of incomes and other taxes as well as the state of the business cycle, downward rigidity of prices and inflationary expectations are certainly factors which will exert a significant influence on prices in the period after VAT introduction (Tait, 1988; Bole 1996). Therefore, one can conclude that dynamic models of general equilibrium would be the most appropriate method to estimate the price effects of VAT introduction. However, as stated by Tait (1988) this approach has not been used by any country. The input - output model can also be a useful method in this respect and it was recently adopted in Slovenia (Bole, 1996). It is also possible to find examples where different surveys have been used to assess possible price reactions (Tait, 1988).

1 The exempt activities are banking industry, medical and cultural services and services of primary schools. 
In the case of Croatia the choice of the estimation method was determined by the availability of statistical data. Input output table do not exist for Croatia. Therefore, analysis of the possible price movements for the basket of goods and services was the only choice left. The idea was to pick a representative sample of goods and services, to analyse the structure of prices in respect to taxes and to determine the actual amount of tax in the price. Knowing the actual amount and share of taxes in the retail prices of chosen goods and services it is possible to isolate the total value added. Knowing also that under certain conditions the multi-stage VAT and single-stage retail tax have the same economic effects the value added computed can be considered as the tax base for the VAT. However, it is necessary to stress that the results we present below are a deterministic and static picture of possible VAT effects. They should be studied and used with a high degree of caution.

In order to analyse the price structure and determine the tax content of prices the data series of the State Bureau of Statistics were used. To be more precise, three series of data were used:

- A series of average producer prices in the Republic of Croatia. This series reflects producer prices reported by the producers themselves. Averaging the data gathered in this way results in a series of average producer prices formorethan 300 products.

- A series of average wholesale prices. Wholesale prices are recorded in four cities, with recording performed by price recorders. Averaging the data gathered in this way results in a series of average wholesales prices for more than 300 products.

- A series of average retail prices in the Republic of Croatia. This series is recorded in 12 cities at 5 to 10 retail locations. The average price in each city is derived via simple arithmetic mean. Weighting factors consist of the shares of a given city in the total retail trade volume of the Republic of Croatia. The series contains average retail prices for more than 400 goods and services.

The basket of goods and services chosen for analysis is the same as the basket used for the calculation of producer price index, wholesale price index and retail price index which are official measures of inflation in Croatia. In this way the final result of our analysis was not only the assessment of price movements for single goods but also an estimate of change in inflation caused by the VAT introduction.

\section{Initial assumptions for predicting the price effects of VAT introduction}

1. In economic terms, VAT that is applied via the credit method according to the destination principle, and a single-stage sales tax that is calculated in retail sales - provided that they are applied at an identical rate and cover the same tax base - have the same effect (Cnossen, 1987). The difference lies solely in the method of legal definition of the taxpayer, since, in economic terms, in both instances, the tax burden is borne by the end consumer. The application of this assumption in our estimation method means that the Croatian tax system must be reduced to a single-stage retail sales tax in order to determine the actual or effective retail sales tax In other words it is necessary to determine which tax rate should be applied on each product and service if single-stage retail tax would have been really applicable in order to keep the final price unchanged. 
When the existing tax system is reduced on single stage retail sales tax than the introduction of VAT simply means to replace calculated actual tax rates with the VAT rate.

2. The following price structure is assumed:

a) The producer price exclusively reflects the costs and profits of the producer, which means that it is assumed that no tax element exists in producer prices;

b) The wholesale price reflects the price of the input (i.e., at producer price) increased by the wholesale trade margin, plus the wholesales tax applicable at the rate of $10 \%$ on wholesalers margin;

c) The retail price reflects the price of the input (i.e., the wholesale price of the goods purchased), plus the retail trade margin plus the sales tax on products plus the $10 \%$ tax on retail trade services. The tax base for sales tax on products is retailer's purchase price increased by his/her margin. The tax rate depends on the type of goods and it is determined by the Rate Schedule of the Law on Sales Tax on Goods and Services. The tax base for the $10 \%$ service tax includes all previously mentioned elements including sales tax on goods.

The assumed price structure clearly indicates that both the sales tax on products and the sales tax on services are partly calculated as a tax on a tax. The appearance of an element of a tax on a tax within the price structure is referred to as a cascading effect. However, this is not the only source which introduces the cascading effect into the existing system of goods and services taxation. The most important sources of cascading are:

a) The already mentioned way that the tax base for tax on services in the retail stage is determined. This causes the tax on services to be charged on a base which includes the full amount of sales tax on goods.

b) The existence of sales tax on wholesaler's services which is charged on wholesaler's margin and makes a part of tax base in the retail phase.

c) The existence of the hidden tax element in the producer prices. Producer prices contain a hidden tax element which is created by the provisions of the Law on the Sales Tax on Goods ${ }^{2}$ The law requires all purchases of liquid fuels and lubricants (or petroleum and petroleum derivatives), office supplies, office furniture, and motor vehicles to be closed at the retail price (with the full amount of sales tax) which means that suspension rule does not operate for these products. It is reasonable to expect that all participants in the production-distribution chains pass on their total costs (including the tax element) to the next participant in the chain. When the sales tax is actually calculated in later phases of the production-distribution chain, then the cascading effect does not appear solely due to the technique of calculating the sales tax on goods and services, but also because the production prices and the trade margins contain a tax element created through the price of the previously mentioned inputs. 
d) The suspension rule does not operate for a certain part of the service sector either. The economic agents who provide personal services (hairdressers, tailors, dry-cleaners etc.) are required to buy their inputs at a price which includes sales tax on goods and services. Since their services are taxable by $10 \%$ service tax this tax is charged on a base which already contains a tax element

As is shown by assumption 2a) the third and fourth sources of cascading have been disregarded in our study. The implication for the understanding of the results is following;

- the results concerning actual tax burden should be understood as minimal tax burden (because we were not able to capture precisely all sources of cascading);

- the estimated price effects should be understood as maximal price effects. As a consequence of our inability to remove tax elements from producer prices the tax base for VAT was overstated. This means that the estimated price effect is the upper limit of the interval.

3. It is assumed that all types of goods that move through the wholesale phase, move through this phase once only. Since the degree of cascading increases with the number of times goods pass through the wholesale phase this assumption contributes to the described way of understanding results.

4. This prediction is based on average prices for April 1996 and directly assumes that the result of the prediction indicates the change in the price index that would occur if a VAT were introduced at the last moment of the April 1996.

\section{An estimate of actually occurring average tax burden}

\subsection{Average tax burden for specific products}

On the basis of the previously described initial assumptions, the prediction method proceeded to develop in two phases. The first phase estimated the actual average tax burden on individual products whose prices participate in calculations of the retail price index. These results provided a basis for estimating the actual average weighted tax burden on consumption. Establishment of the average tax burden for individual products, i.e., establishment of the weighted average tax burden in consumption, is significant for the following reasons:

a) establishing the average tax burden of products that participate in calculations of the price index means, in actuality, establishing the "average actual or effective tax rate" that - on condition that the existing sales tax is actually a single stage retail sales tax - should be applied to a given product so that its price and the absolute amount of tax remain unchanged. By this procedure, in accordance with the assumption concerning the economic identity of VAT and the retail sales tax, we ensure that the existing tax and VAT are comparable. Furthermore, the elements for reconstructing the tax base for VAT and carrying out the second phase in the prediction procedure is established. 
b) establishing the current total weighted tax burden in consumption and its comparison with the VAT rate as a measure of the tax burden under conditions of the new tax show the general direction of shift in the price index that can be expected after introduction of the VAT.

The idea is to establish the existing average tax burden by comparing a series of producer, wholesale, and retail prices and then to discover for which products we have all three prices available. It has been established that there are 80 products which are simultaneously recorded at the level of producer prices, wholesale prices and retail prices. A sample of 80 products made it possible to compare the three prices and then, via appropriate mathematical operations (which we describe in detail in the Appendix ), to calculate the tax on the wholesale margin, the sales tax on goods, and the sales tax on retail services, i.e., to establish the actual share of tax in the price (of course, under conditions of the assumptions described above). The results obtained by comparing the prices of these 80 products are shown in the Table 1 . The Table 1 shows the average retail price (MPC), the retail price (VA) from which all taxes have been excluded and the real average tax burden of the individual product.

Table 1. Real Average Tax Burden

\begin{tabular}{|c|c|c|c|}
\hline Product & $\begin{array}{l}\text { Average } \\
\text { Retail Price } \\
\text { MPC }\end{array}$ & $\begin{array}{l}\text { Average Retail } \\
\text { price, Excluding } \\
\text { Tax (VA) }\end{array}$ & $\begin{array}{l}\text { Real Average } \\
\text { Tax Burden, } \\
\text { in \% }\end{array}$ \\
\hline 1 & 2 & 3 & 4 \\
\hline 1 Wheat flour & 4.02 & 3.43 & 17.15 \\
\hline 2 Egg noodles & 11.63 & 10.03 & 15.95 \\
\hline 3 Cookies and crackers & 32.17 & 27.43 & 17.30 \\
\hline 4 Baby food & 48.91 & 42.29 & 15.66 \\
\hline 5 Tomato paste & 51.24 & 42.67 & 20.09 \\
\hline 6 Canned peas & 13.59 & 11.40 & 19.17 \\
\hline 7 Marmalade & 22.66 & 18.86 & 20.12 \\
\hline 8 Raspberry juice & 17,70 & 15,23 & 16,22 \\
\hline 9 Boiled ham & 58.13 & 48.94 & 18.78 \\
\hline 10 Beef stew & 44.04 & 37.55 & 17.27 \\
\hline 11 Sardines in oil & 36.95 & 29.66 & 24.58 \\
\hline 12 Lard & 12.71 & 12.66 & 0.42 \\
\hline 13 Vegetable oil & 10.31 & 10.29 & 0.18 \\
\hline 14 Margarine & 15.72 & 15.60 & 0.80 \\
\hline 15 Trappist cheese & 47.43 & 40.82 & 16.19 \\
\hline 16 Sugar & 6.42 & 6.05 & 6.07 \\
\hline 17 Cooking chocolate & 53.12 & 46.08 & 15.28 \\
\hline 18 Milk chocolate & 62.68 & 54.33 & 15.37 \\
\hline 19 Candy & 46.03 & 39.50 & 16.53 \\
\hline 20 Coffee beans & 83.86 & 64.80 & 29.42 \\
\hline 21 Salt & 3.16 & 2.61 & 21.18 \\
\hline 22 Vinegar & 7.12 & 5.92 & 20.36 \\
\hline 23 Chicken soup & 4.24 & 3.59 & 18.07 \\
\hline 24 'Vegeta' & 58.39 & 49.87 & 17.09 \\
\hline
\end{tabular}




\begin{tabular}{|c|c|c|c|}
\hline 25 Wine & 13.03 & 9.57 & 36.10 \\
\hline 26 Brandy 1 & 47.29 & 33.37 & 39.96 \\
\hline 27 Vinjak 2 & 55.04 & 39.64 & 38.86 \\
\hline 28 Combed wool fabric & 132.40 & 103.77 & 27.59 \\
\hline 29 Combed blend fabric & 103.19 & 80.85 & 27.63 \\
\hline 30 Dress goods & 128.55 & 102.68 & 26.23 \\
\hline 31 Sheeting & 33.25 & 26.28 & 27.50 \\
\hline 32 Lining material & 37.84 & 29.34 & 28.97 \\
\hline 33 Man's shirt, $100 \%$ cotton & 231.54 & 178.39 & 29.79 \\
\hline 34 Man's shirt, blend & 212.79 & 164.41 & 29.42 \\
\hline 35 Man's undershirt & 35.22 & 26.87 & 31.09 \\
\hline 36 Man's poplin undershirts & 56.80 & 43.06 & 31.91 \\
\hline 37 Men's cotton socks & 20.42 & 15.75 & 29.65 \\
\hline 38 Men's stockings & 15.21 & 11.49 & 32.40 \\
\hline 39 Children's leggings & 19.42 & 16.30 & 19.11 \\
\hline 40 Women's nylon stockings & 18.82 & 14.66 & 28.37 \\
\hline 41 Set of bed linen & 280.47 & 221.72 & 27.50 \\
\hline 42 Cotton thread & 2.75 & 2.13 & 28.98 \\
\hline 43 Heating oil & 2.05 & 1.78 & 15.00 \\
\hline 44 Matches & 0.51 & 0.40 & 28.53 \\
\hline 45 Electric range & 2165.55 & 1711.90 & 26.50 \\
\hline 46 Combination range & 2460.91 & 1945.38 & 26.50 \\
\hline 47 Water heater & 1244.3 & 981.06 & 26.83 \\
\hline 48 Electric iron & 239.1 & 184.30 & 29.73 \\
\hline 49 Enamelled range & 2345.92 & 1830.35 & 28.17 \\
\hline $50 \mathrm{Wood} /$ coal stove & 2445.44 & 1901.58 & 28.60 \\
\hline 51 Light bulb & 4.09 & 3.13 & 30.61 \\
\hline 52 Enamelled saucepan & 72.78 & 56.95 & 27.79 \\
\hline 53 Tableware & 562.12 & 432.84 & 29.87 \\
\hline 54 Soup plate & 20.41 & 15.73 & 29.75 \\
\hline 55 Demitasse & 17.86 & 14.08 & 26.88 \\
\hline 56 Washing machine detergent & 15.48 & 13.49 & 14.77 \\
\hline 57 Toilet soap & 39.91 & 34.40 & 16.03 \\
\hline 58 Shampoo & 14.34 & 12.29 & 16.66 \\
\hline 59 Tooth paste & 8.61 & 7.28 & 18.31 \\
\hline 60 Face cream & 9.38 & 7.09 & 32.39 \\
\hline 61 Shoe polish & 6.27 & 4.84 & 29.52 \\
\hline 62 Analgesics & 9.78 & 8.41 & 16.31 \\
\hline 63 Antipyretics & 3.8 & 3.12 & 21.94 \\
\hline 64 Cough syrup & 48.11 & 39.12 & 22.97 \\
\hline 65 Vitamin C & 13.22 & 10.65 & 24.07 \\
\hline 66 School notebook & 3.43 & 2.92 & 17.33 \\
\hline 67 Motor gasoline 86 oct. & 3.6 & 2.88 & 20.00 \\
\hline 68 Motor gasoline 98 oct. & 4 & 3.2 & 20.00 \\
\hline 69 Motor oil & 19.92 & 16.23 & 22.72 \\
\hline 70 Brick, solid & 2.07 & 1.70 & 21.64 \\
\hline 71 Construction tile & 3.75 & 2.99 & 25.45 \\
\hline 72 Hollow brick & 1.57 & 1.27 & 23.81 \\
\hline 73 Cement & 0.66 & 0.53 & 24.32 \\
\hline 74 Lime & 0.77 & 0.61 & 26.80 \\
\hline
\end{tabular}




\begin{tabular}{||l|r|r|r||}
\hline 75 Roofing material & 150.14 & 119.85 & 25.27 \\
\hline 76 Chipboard & 1441.04 & 1166.59 & 23.53 \\
\hline 77 Fir boards & 1504.28 & 1244.79 & 20.85 \\
\hline 78 Nails & 12.12 & 9.82 & 23.43 \\
\hline 79 Synthetic white paint & 44.56 & 33.76 & 31.99 \\
\hline 80 Wallpaper & 39.32 & 30.62 & 28.42 \\
\hline
\end{tabular}

It is possible to describe the results given in column 4 as the tax rate of the sales tax which should be applied if the one-stage retail sales tax were actually in force.

The results obtained show that even on the assumption that no tax element is contained in the producer price and trade margins the average tax burden on the product is higher than the burden derived directly from the rate schedule of the Law on the Sales Tax on Goods and Services. This result is logical and obvious, since in addition to the cascading effect which results from the method of computation of the sales tax on services in the retail sector, the tax burden on wholesale trade by the sales tax on services adds additional strength to the cascading effect. However, it is necessary to keep in mind that because of the assumptions described in section 2 the results obtained do not include all sources of cascading. Therefore, the computed average tax burden (Table 1 - column 4) represents the minimal actual (effective) tax rate applied to stated products.

\subsection{Average tax burden for the whole sample of goods and services}

The results obtained for these 80 products, which constitute a cross section of producer, wholesale, and retail price series (Table 1), were transferred to all goods and services covered by the index based on the following assumptions:

a) for the 80 products whose price structure has been analysed in detail in the manner previously described, the calculated average tax burden was taken into account in estimating the total average tax burden on consumption.

- $\quad$ for products of similar type and purpose as the products in Table, it was assumed that their tax burden could be approximated by the computed burden for the similar product. For example, the tax burden on the products 'waffle cookies' and 'crackers' was approximated by the burden calculated for the product category 'cookies and crackers.'

b) It was assumed that the average tax burden on agricultural products is $8.5 \%$. That is, the average price of individual farm products which enter into the computation of the retail price index is obtained from registered retailers but also from the farmers' markets. The products which farmers bring to the open-air market are exempted from any tax, while fresh farm products in the retail trade sector are burdened with a $5 \%$ sales tax and $10 \%$ service tax. Therefore, it is assumed that into the computation of the average Croatian price (which shows up in the retail price index) $45 \%$ of products enter the sales tax on goods and services and $55 \%$ with the tax. 

actual tax burden, as well as for all services, we assumed that their burden is equal to the rates of the sales tax on goods and services given in the Rate Schedule of the Law on the Sales Tax on Goods and Services. ${ }^{7}$ For all the reasons given above (the cascade effect which comes from petroleum products, the number of various merchants through whose hands the product passes before reaching the final consumer) it is highly likely that the actual tax burden of these products is also higher. Once again, for interpretation of the results this means that the minimum tax burden was used.

Following these assumptions and using the system of weights normally used to compute the retail price index, we estimated the total average tax burden on goods and services at the point of consumption. The results in Table 2 show the estimated total tax burden on products at the point of consumption or the average tax burden on various product groups.

Table 2. Estimated Actual Average Burden in the Retail Price Index, by product groups

\begin{tabular}{|c|c|}
\hline Product Group & Average Burden, in \% \\
\hline TOTAL & 18.43 \\
\hline I. Goods & 20.54 \\
\hline 1. Farm products & 8.50 \\
\hline Fresh vegetables & 8.50 \\
\hline Fresh fruit & 8.50 \\
\hline 2. Industrial products & 20.92 \\
\hline 2.1. Industrially produced foodstuffs & 13.61 \\
\hline Grain products & 7.56 \\
\hline Bread and alimentary pastes & 5.00 \\
\hline Processed and canned vegetables & 17.96 \\
\hline Processed and canned fruit & 17.27 \\
\hline Fresh meat & 15.50 \\
\hline Processed and canned meat & 18.34 \\
\hline Processed and canned fish & 24.58 \\
\hline Fresh and processed milk & 3.34 \\
\hline Fats & 0.34 \\
\hline Confections & 16.42 \\
\hline Beverages & 35.49 \\
\hline Tobacco & 20.00 \\
\hline 2.2. Non-food industrial products & 22.38 \\
\hline Textile products & 28.69 \\
\hline Leather goods & 25.21 \\
\hline Lighting and heating & 19.44 \\
\hline
\end{tabular}

The rate given in the Rate Schedule of the Law on the Sales Tax on Goods and Services was assumed for 127 products. Their weights represent $33.92 \%$ of the sum of all weights. The tax burden on all services, which constitute $18.32 \%$ of the weights, was assumed in the same way. 


\begin{tabular}{||l|c||}
\hline Housewares & 27.70 \\
\hline Toiletries & 22.45 \\
\hline Drugs and related items & 17.69 \\
\hline Educational, cultural, and recreational goods & 4.45 \\
\hline Vehicles & 26.50 \\
\hline Liquid fuels and lubricants & 20.19 \\
\hline Building materials & 23.09 \\
\hline II Services & $\mathbf{1 0 . 0 0}$ \\
\hline
\end{tabular}

The results obtained need to be interpreted as follows: the total average tax burden on goods and services included in the retail price index is at minimum of $\mathbf{1 8 . 4 3 \%}$. We interpret the remaining results in the same way. The minimum tax burden was estimated for, agricultural products at $8.5 \%$, and industrially produced foodstuffs at $13.61 \%$. Industrial non-food products have a burden of at least $22.38 \%$, in which textiles products have a burden of at least $28.69 \%$, lighting and heating at least $19.41 \%$, and housewives at least $27.7 \%$. The minimum tax burden on services is $10 \%$.

These results indicate the direction of movements in the prices of the analysed groups of products as well as in the aggregate retail price index after the VAT introduction. That is, in line with the conventional conclusion about the price movements caused by VAT introduction, VAT can cause changes (increase) in the aggregate price if the VAT rate is different (higher) than the existing effective tax burden. On the other hand the existing effective tax burden depends on the existing average tax rate and on the degree of the cascading effect (See, 1993).

\section{Projection of changes in the price index after the introduction of VAT}

Starting from the actual average tax burden computed in the manner described previously 'pure' average price is computed for every item in the chosen sample of goods and services. 'Pure' average price is computed as a ratio of retail price and computed actual tax rate for every item in the sample. Under the assumptions defined in Section 2'pure' price does not contain any element of the sales tax on goods and services and therefore it can be considered as a good approximation of the tax base for the value added tax. As we have already stated, the multi-phase is equal in its economic effects to the retail sales tax on goods and services calculated at the same rate in the last phase of the production-distribution chain. Using this knowledge the price which should exist in the VAT regime was reconstructed in the following way: 'pure' average price (computed as a ratio of retail price and calculated actual average tax rate) has been multiplied by the VAT tax rate i. e. $22 \%$. It is also assumed that the prices of exempt services will remain unchanged. ${ }^{\text {D }}$

Two scenarios were tested in forecasting the possible shift of the price index following the introduction of

6 If a product or service has been exempted, this means that the legal entity producing or selling that product of offering that service does not compute the VAT on its product or service. However, at the same time that legal entity does not have the right to a refund of previously paid tax. This means that the price of his product or service, although formally exempt, does contain an element of tax paid in the price of the input. Assuming that the price of these products and services will in the context of VAT remain equal to the present price, we assume that the sales tax that exists today in the price is sufficient compensation for the VAT which those legal entities will pay in the price of the input and will very likely pass on through costs to the buyers of their products or services. 
VAT. A subvariant was also computed for each of the main scenarios, differing from the main scenario only in the treatment of personal services and services of the crafts and trades.

\section{FIRST SCENARIO}

The assumption is that all producers and merchants in all value added chains begin to compute the tax with 'maximum accuracy' immediately after VAT is introduced. In other words, the effects were studied of a scenario in which products subject today to actual sales tax rates (in the sense of the rates estimated in the previous section) lower than the VAT rate become more expensive precisely by the difference between the actual rate and the VAT rate. Likewise, products which are today taxed at actual rates higher than the VAT rate become cheaper by the amount of the difference between those rates. For all exempted services (i.e. the renting out of housing, medical services, schools, etc.) it is assumed that after the introduction of VAT the price will remain unchanged or equal to the price which that service has today. In mathematical terms the assumptions of this scenario were implemented by calculating the rate of $22 \%$ on the 'pure' average price established in the manner described previously. This scenario obviously neglects downward price rigidity and assumes that the absolute (kuna) amount of trade margins and producer profits remains unchanged.

The subvariant of this scenario tests the effects of the previous assumptions under conditions where craftsmen and tradesmen and those offering personal services remain outside the VAT system. That is, the Law on the Value Added Tax provides that all those who have an annual volume of sales less than HRK 50,000 (app. 8,300 USD) may remain outside the VAT system, which means that their position is the same as the position of final consumers. They do not calculate the VAT on their products, but they pay it when they purchase inputs necessary to conducting their business. Therefore, the subvariant posits the same initial conditions as the main scenario, but craftsmen and tradesmen and those rendering personal services are left out of the VAT system. Exclusion of this category of services assumes that their prices will remain at the level they had in the month when this research was conducted for the reasons stated in Note 6 .

\section{SECOND SCENARIO}

The assumption is that all producers and merchants whose products are today taxed at higher actual rates than the rate of VAT will simply syphon off the reduction of the tax burden - by which they should really have reduced their price - into their profit margins. In other words, the purpose of this scenario was to test what would happen to the price index if all the products and services, which today have a lower actual tax burden than the tax burden introduced with VAT, become more expensive, and the prices of all other products remain unchanged. Just as in the previous scenario, it is assumed that the prices of the exempted products remain unchanged and that all services are in the VAT system.

The subvariant of this scenario tests the effect of excluding personal services and those of craftsmen and tradesmen (and of maintaining their prices at the present level) under the conditions of the assumptions of the second scenario. 


\section{Results of the Forecasts}

The results of the forecasting exercise under the conditions of the scenarios described are shown in Table 3. It is important to keep in mind that the results should be interpreted with the exceptional caution because of the restrictive nature of underlying assumptions According to the general assumptions of the entire forecasting procedure and the specific assumptions of each scenario every forecaster value of the price index shown in Table 3 should be interpreted as the maximum change in price index which can be caused, all other thing being equal, by VAT introduction. All the values shown are the maximum values of the change in price index because it was assumed that there is no cascading effect in the value added chain prior to the production phase (Section 2). Furthermore, because of the unavailable data it was also assumed that the actual tax burden of all services and some products is equal to the tax burden defined by the Rate Schedule of the Law on Sales Tax on Goods and Services.

Accordingly, since it was nevertheless not possible to altogether remove the entire cascading effect in the process of making this forecast, that is, to remove all tax from the price, this means that we can nevertheless expect that at the present time the tax burden in the price is somewhat greater than that assumed in projection of the price index. Consequently, if the actual tax burden is greater than was assumed in the computation, then if the VAT is computed correctly and accurately, the real upward price change should be less, and the real downward price change should be greater. As a consequence the value of the price index should be smaller.

The results presented in Table 3 show that if the first scenario is borne out, and VAT is applied with perfect accuracy, prices might increase at the most by $3.27 \%$. In a breakdown by components this means that farm products could on the average become at the most $12.4 \%$ more expensive, while at the aggregate level average prices of industrial products could increase by $1.33 \%$. Industrially produced foodstuffs could become at the most $7.87 \%$ more expensive (with variations within the group from a possible price drop for processed and canned fish of at least $2.07 \%$ to a price rise of the bread and macaroni group by a maximum of $16.72 \%$ and the fats group by a maximum of $21.58 \%$ ), while non-food industrial products could become at least $0.2 \%$ cheaper. The total result of the price drop of industrial non-food products by at least $0.12 \%$ results from variation within the group, which ranges from a possible price rise of $15.97 \%$ at most for the group of educational and cultural goods to a possible price drop of at least $5.35 \%$ for textile products. In this scenario services could at most become $10.8 \%$ more expensive. 
Table 3.

Maximum one-time Change in Prices

\begin{tabular}{|c|c|c|c|c|c|c|c|c|c|}
\hline & \multirow[b]{2}{*}{ Name } & \multicolumn{2}{|c|}{ SCENAR $][O 1$} & \multicolumn{2}{|c|}{ SCENARIO 1/1 } & \multicolumn{2}{|c|}{ SCENAR] O 2} & \multicolumn{2}{|c|}{ SCENAR] O 2/1 } \\
\hline & & Index & $\begin{array}{l}\text { te of } \\
\text { inge }\end{array}$ & Index & $\begin{array}{l}\text { Rate of } \\
\text { change }\end{array}$ & Index & $\begin{array}{l}\text { ite of } \\
\text { ange }\end{array}$ & Index & $\begin{array}{l}\text { ate of } \\
\text { ange }\end{array}$ \\
\hline 1 & 2 & 3 & 4 & 5 & 6 & 7 & 8 & 9 & 10 \\
\hline & AGREGATE PRICE INDEX & 103.27 & 3.27 & 102.77 & 2.77 & 105.20 & 5.20 & 104.70 & 4.70 \\
\hline 110 & Farm products & 112.40 & 12.40 & 112.40 & 12.40 & 112.40 & 12.40 & 112.40 & 12.40 \\
\hline & Fresh vegetables & 112.50 & 12.50 & 112.50 & 12.50 & 112.50 & 12.50 & 112.50 & 12.50 \\
\hline & Fresh fruit & 112.40 & 12.40 & 112.40 & 12.40 & 112.40 & 12.40 & 112.40 & 12.40 \\
\hline 120 & Industrial products & 101.33 & 1.33 & 101.33 & 1.33 & 103.75 & 3.75 & 103.74 & 3.74 \\
\hline 121 & Industrially produced foodstuff & $\mathbf{1 0 7 . 8 7}$ & 7.87 & 107.87 & 7.87 & 108.07 & 8.07 & 108.07 & 8.07 \\
\hline & Grain products & 114.07 & 14.07 & 114.07 & 14.07 & 114.07 & 14.07 & 114.07 & 14.07 \\
\hline & Bread and alimentary pastes & 116.72 & 16.72 & 116.72 & 16.72 & 116.72 & 16.72 & 116.72 & 16.72 \\
\hline & Processed and canned vegetables & 103.49 & 3.49 & 103.49 & 3.49 & 103.49 & 3.49 & 103.49 & 3.49 \\
\hline & Processed and canned fruits & 104.12 & 4.12 & 104.12 & 4.12 & 104.12 & 4.12 & 104.12 & 4.12 \\
\hline & Fresh meet & 105.63 & 5.63 & 105.63 & 5.63 & 105.63 & 5.63 & 105.63 & 5.63 \\
\hline & Processed and canned meat & 103.08 & 3.08 & 103.08 & 3.08 & 103.08 & 3.08 & 103.08 & 3.08 \\
\hline & Processed and canned fish & 97.93 & -2.07 & 97.93 & -2.07 & 100.00 & 0.00 & 100.00 & 0.00 \\
\hline & Processed and canned milk & 113.42 & 13.42 & 113.42 & 13.42 & 113.42 & 13.42 & 113.42 & 13.42 \\
\hline & Fats & 121.58 & 21.58 & 121.58 & 21.58 & 121.58 & 21.58 & 121.58 & 21.58 \\
\hline & Sweets & 104.80 & 4.80 & 104.80 & 4.80 & 104.80 & 4.80 & 104.80 & 4.80 \\
\hline 122 & Beverages & 90.57 & -9.43 & 90.57 & -9.43 & 100.00 & 0.00 & 100.00 & 0.00 \\
\hline 123 & Tobacco & 101.67 & 1.67 & 101.67 & 1.67 & 101.67 & 1.67 & 101.67 & 1.67 \\
\hline 124 & Non-food industrial products & 99.88 & -0.12 & 99.88 & -0.12 & 102.74 & 2.74 & 102.74 & 2.74 \\
\hline & Textile products & 94.65 & -5.35 & 94.65 & -5.35 & 100.20 & 0.20 & 100.20 & 0.20 \\
\hline & Leather goods & 97.51 & -2.49 & 93.90 & -6.10 & 100.66 & 0.66 & 100.66 & 0.66 \\
\hline & Lighting and heating & 102.36 & 2.36 & 102.36 & 2.36 & 103.70 & 3.70 & 103.70 & 3.70 \\
\hline & Housewares & 95.55 & -4.45 & 95.55 & -4.45 & 100.00 & 0.00 & 100.00 & 0.00 \\
\hline & Toiletries & 100.25 & 0.25 & 100.25 & 0.25 & 102.70 & 2.70 & 102.70 & 2.70 \\
\hline & Medical supplies & 100.72 & 0.72 & 100.72 & 0.72 & 101.38 & 1.38 & 101.38 & 1.38 \\
\hline & Items for entertainment and culture & 115.97 & 15.97 & 115.97 & 15.97 & 116.40 & 16.40 & 117.40 & 17.40 \\
\hline & Vehicles & 96.44 & -3.56 & 96.44 & -3.56 & 100.00 & 0.00 & 100.00 & 0.00 \\
\hline & Liquid fuels and lubricants & 101.50 & 1.50 & 101.50 & 1.50 & 101.50 & 1.50 & 101.50 & 1.50 \\
\hline & Building material & 99.13 & -0.87 & 99.13 & -0.87 & 100.28 & 0.28 & 100.28 & 0.28 \\
\hline 200 & Services & 110.45 & 10.45 & 107.72 & 7.72 & 110.45 & 10.45 & 107.72 & 7.72 \\
\hline
\end{tabular}


Examining the results of the first scenario shown in Columns 4-7, and of the results of the second scenario presented in Columns 8-11, we see that the shift of the price index is largely under the influence of the change in the prices of farm products and industrially produced foodstuffs. As shown by Columns 2 and 3, the change in the price of agricultural products and industrially produced foodstuffs alone would result in a $1.7 \%$ rise of the index, that is, a $1.7 \%$ single inflationary shift.

The second scenario, whose purpose was to study the possible shift of the index on the assumption that no one lowers prices shows that this highly adverse development of events could result in a maximum 5.2\% rise in price index. In that case the prices of agricultural products might rise by a maximum of $12.4 \%$, while the rise of the prices of industrial products might amount to a maximum of $3.74 \%$, with variations from component to component, as shown by Columns 7 and 8 in Table 3. Under the conditions of this scenario services could become at most 10.8 more expensive, just as under the conditions of the first scenario.

The subvariant of the second scenario, which investigates the effect of excluding certain services from the system, while maintaining their prices at the present level, shows that the aggregate impact of this situation might be an increase in price index by a maximum of $4.7 \%$, where, assuming all the other results equal to the results of the main scenario (Columns 7 and 8), services would become at the most $7.72 \%$ more expensive.

The purpose of the scenarios tested was obviously to investigate the effects of two extreme assumptions. Ideal and correct application of VAT from the first moment of its introduction is described by the first scenario, which we can therefore refer to as the 'optimistic' scenario. At the same time, the second scenario registers a markedly pessimistic assumption conceming the behaviour of producers and merchants whose products are subject to high rates today. However, taking into the account all previously mentioned assumptions both scenarios indicate the possibility of a one-time shift in prices. It is also quite obvious that increase in the prices of services contribute significantly to the increase in the aggregate price index.

We can realistically anticipate that actual price shifts in the first month of application of the VAT will be somewhere between these two extremes. That is, there will probably be certain difficulties in the application either because taxpayers do not get their bearings or the tax administration may be at a loss. Likewise, it is to be expected that downward price rigidity will not be perfect, so that products which experience a decrease in tax burden will nevertheless become cheaper to a greater or lesser extent. This leads us to the conclusion that we should interpret the results of our forecasts also as indicating the upper limits of the interval within which we can expect a one-time shift of prices.

\section{Conclusion}

As shown by the experience of other countries, VAT may cause a rise of prices during the period immediately after its introduction. However, it has also been shown that the impact of the tax reform was a one-time shift in prices. This means that the answer to the question of whether the introduction of VAT will cause a continued rise of prices, or inflation, depends on factors outside the fiscal reform itself. The decisive factors are the level of the development of market mechanisms, the moves made in economic policies, the phase of the economic cycle in which economy finds itself at the moment of VAT introduction, income policies and numerous psychological factors (Tait, 1988, 
1990).

The forecast of the price effects of the introduction of VAT in the Republic of Croatia shows that the present average tax burden amounts to a minimum of $18.43 \%$. Depending on the degree of cascading prior to the wholesale stage (which we were not able to capture) it is possible to conclude that there is certain amount of room for the aggregate price increase. Taking into account that in the first months of VAT's effect there will be some difficulties, and assuming that prices will not display perfect downward rigidity, the forecast shows that the aggregate rise of prices (measured by the retail price index) could be a maximum of $3.27 \%$ (optimistic scenario) or a maximum of 5.2\% (pessimistic scenario) - both on the assumption of zero cascading before the wholesale stage.

These results obviously suggest the conclusion that as far as the introduction of VAT is concerned, at least during the first half of next year, neither monetary policy nor exchange rate policy should adapt to the shift of prices. In other words, at least during the first half of next year monetary aggregates and also the exchange rate should remain on the trajectory and within the intervals shaped in the course of this year. At the same time, wages and salaries, at least in the first half of next year, ought to remain nominally unchanged, which would prevent a price-wage spiral from getting started. 


\section{Appendix: Procedure for calculation of the actual average tax burden}

Proceeding from the assumptions established in Section 2, we may define wholesale price (VPC) as follows:

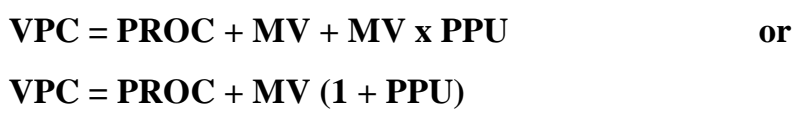

where PROC is producer price, MV is the wholesale margin, and PPU is the rate of the sales tax on wholesale services, i.e., 10 percent.

On the basis of equation (1), it follows that the kuna amount of the sales tax on wholesale services, as shown by equation (2), may be calculated on the basis of the difference between the producer and wholesale prices. In actuality, this difference represents the wholesale margin increased by the sales tax on wholesale services.

$$
M V_{P P U}=\text { VPC }- \text { PROC }
$$

where $\mathrm{MV}_{\mathrm{PPU}}$ is the wholesale margin including the tax on wholesale services.

Dividing this difference by the expression $(1+$ PPU), where PPU is the sales tax rate on services, we obtain, from expression (3), the size of the wholesale margin, MV.

$$
\mathrm{MV}=\mathbf{M V} \mathbf{P P U}_{\mathbf{P U}} /(1+\mathrm{PPU})
$$

Clearly, the difference between the margin increased by the sales tax on wholesale services and "net" margin minus tax is the kuna value of the sales tax on wholesale services.

$$
P P U_{V}=M V_{P P U}-M V
$$

where $P P U_{V}$ is the kuna amount of sales tax on wholesale services.

The following structure is assumed for a retail price:

$$
M P C=[(V P C+M M) \times(1+P P P)] \times(1+\text { PPU })
$$

where MPC is the retail price, VPC is the wholesale price, MM is the retail trade margin, PPP is the sales tax rate on goods according to the rate schedule in the Law on the Sales Tax on Goods, PPU is the sales tax rate on retail services according to the Law on the Sales Tax on Services.

From expression (5) it follows that the kuna amount of sales tax on goods and sales tax on services that are calculated in retail trade may be figured via the following method: 
where $\mathrm{PP}_{\mathrm{M}}$ is the kuna amount of the tax that is figured during the retail phase.

At the same time, it is also possible to figure the "net" retail price (MPC), from which are excluded taxes calculated during the retail phase via the following expression:

$$
\mathrm{MPC}_{\mathrm{F}}=\mathrm{MPC} /[(1+\mathrm{PPP}) \times(1+\mathrm{PPU})]=(\mathrm{VPC}+\mathrm{MM})
$$

On the basis of this expression, it clearly follows that the retail trade margin (i.e., costs and profit of retail trade) is equal to the difference between the wholesale and "net" retail prices, i.e., $\mathrm{MPC}_{\mathrm{F}}$

$$
\mathrm{MM}=\mathrm{MPC}_{\mathrm{F}}-\mathrm{VPC}
$$

The arithmetic operations described ensure the elements necessary to establish: overall sales tax in the average price of the goods under consideration; a reconstruction (stated conditionally) of the price that would exist under conditions without any sales tax; and an estimate of the average tax rate with which each product examined is burdened.

\section{REFERENCES}

Bole, Velimir (1996): "Davek na dodanu vrednost, tečaj in plače", Gospodarska Gibanja, No. 269, pp. 21-34

Cnossen, Sijbren: "VAT and RST: A Comparison ", Canadian Tax Journal, May/June 1987.

Tait, Alan (1988): "Value Added Tax: International Practice and Problems", IMF.

Tait, Alan (1990): "Revenue, Inflation and the Foreign Trade Balance" in Gillis, Malcom, C.S. Shoup, G.P. Socat (ed.): "Value Added Taxation in Developing Countries", World Bank Symposium, Washington, pp. 17-32.

Zee, Howell H. (1995): "Value Added Tax" in Parthasarathi, Shome (ed.): Tax Policy Handbook, IMF, Washington.

...Zbirka propisa o porezu na promet proizvoda, Institut za javne financije, Zagreb, 1996

...Zakon o porezu na dodanu vrijednost, Narodne novine, br. 47/95 